Discussion

\title{
Reply to the comment by Quartau and Mitchell on "Reconstructing the architectural evolution of volcanic islands from combined K/Ar, morphologic, tectonic, and magnetic data: The Faial Island example (Azores)", J. Volcanol. Geotherm. Res. 241-242, 39-48, by Hildenbrand et al. (2012)
}

\author{
A. Hildenbrand ${ }^{\text {a,b, },}$, F.O. Marques ${ }^{\text {c }}$, A.C.G. Costa ${ }^{\text {a,c }}$, A.L.R. Sibrant ${ }^{\text {a,c }}$, P.F. Silva ${ }^{\text {d }}$, B. Henry ${ }^{\text {e }}$, \\ J.M. Miranda ${ }^{\text {, }}$, P. Madureira ${ }^{\mathrm{f}, \mathrm{g}}$ \\ a Univ Paris-Sud, Laboratoire IDES, UMR8148, 91405 Orsay, F-91405, France \\ ${ }^{\mathrm{b}}$ CNRS, Orsay, F-91405, France \\ c Universidade de Lisboa, IDL, Lisboa, Portugal \\ d ISEL/DEC and IDL/CGUL, Lisboa, Portugal \\ e Paleomagnetism, IPGP and CNRS, 4 Av. de Neptune, 94107 Saint-Maur cedex, France \\ ${ }^{\mathrm{f}}$ Centro de Geofisica de Évora and Dep. de Geociências da Univ. de Évora, R. Romão Ramalho, 59, 7000-671 Évora, Portugal \\ g Estrutura de Missão para a Extensão da Plataforma Continental, R. Costa Pinto, 165, 2770-047, Paço D'Arcos, Portugal
}

\section{A R T I C L E I N F O}

Article history:

Received 20 January 2013

Accepted 23 January 2013

Available online 31 January 2013

In our recent paper (Hildenbrand et al., 2012a), we used a panel of complementary approaches to reconstruct the architectural evolution of Faial oceanic island over the last $1 \mathrm{Myr}$. We showed that the present island has a complex architecture, which results from distinct and brief $(<50 \mathrm{kyr})$ episodes of volcanic construction separated by long periods of volcanic inactivity, during which the edifices were extensively dismantled by erosion and tectonics. The upper part of the oldest volcanic system, especially, only crops out in the SE part of the island, whereas most of the original volcano was deeply modified by mass wasting processes and extensively covered by more recent volcanic products. The combination of our $\mathrm{K} / \mathrm{Ar}$, morphologic, tectonic and magnetic data suggests that the remnants of the old volcano are presently under most of Faial, and that this volcano had an elongated morphology slightly oblique with respect to the present WNW-ESE elongation of the island. In their comment, Quartau and Mitchell point out possible "problems" in our interpretations. Their only criticism lies on the extent and morphology of the old volcano, which they draw as a small conical edifice restricted to the eastern end of the island.

DOI of original article: http://dx.doi.org/10.1016/j.jvolgeores.2012.06.019.

* Corresponding author at: Univ Paris-Sud, Laboratoire IDES, UMR8148, 91405 Orsay,

F-91405, France. Tel.: + 331691567 42; fax: + 33169154891 .

E-mail address: anthony.hildenbrand@u-psud.fr (A. Hildenbrand).
We thank Quartau and Mitchell for giving us the opportunity to clarify some important points and discuss significant problems regarding their interpretations:

(1) On-land and offshore topographic data, indeed, provide useful information regarding slope processes on oceanic islands (e.g., Hildenbrand et al., 2006). However, they only give an instantaneous picture of the present edifice morphology. In their comment, Quartau and Mitchell show the bathymetry close to the Faial Island shorelines, and focus more specifically on shallow insular shelves located a few hundred meters away from the present sea cliffs. In their interpretation, the distribution of these shelves would mimic the original slopes of the old volcano. In this interpretation, they assume that (a) the volcano has not experienced any subsequent morphological evolution throughout the lifetime of the island, and (b) the present morphology of the upper proximal submarine slopes is representative of the full geometry of the volcanic edifice. In Fig. 1 of their comment, Quartau and Mitchell present a close-up of the submarine flank, and draw two main volcanoes with a circular shape in plan view. From the extent of these circles, and consideration about statistical slope distribution (Fig. 2 of their comment), they claim that the $800 \mathrm{~m}$ isobath materializes the "bathymetric base" of the island. However, they restrict their analysis to the upper submarine slopes, especially in the southern sector, while deeper features on the northern flank are ignored. Previous data by Mitchell et al. (2003) provide a more coherent view at a more appropriate scale (Fig. 1). These clearly show that Faial is only the emerged western part of a much larger volcanic complex, the Pico-Faial ridge, which sits on top of the Azores plateau, down to depths between $1200 \mathrm{~m}$ and $1400 \mathrm{~m}$ below sea level. While the morphology of the southern flank is disturbed by submarine ridges parallel to the island, the distal bathymetry $\mathrm{N}$ of Faial shows a large low-slope relief (Fig. 1), which could either 